\title{
ANALISIS KINERJA KEUANGAN PERUSAHAAN \\ TERHADAP KEPEMILIKAN MANAJERIAL (Studi Kasus pada Perusahaan Retail Yang Terdaftar di BEI)
}

\author{
Aris Sunandes \\ Dosen Fakultas Ekonomi Universitas Islam Balitar Blitar \\ e-mail: arissunandes@unisbablitar.ac.id
}

\begin{abstract}
ABSTRAK
Penelitian ini bertujuan untuk mendapatkan bukti secara empiris tentang pengaruh kinerja keuangan perusahaan retail yang terdaftar di Bursa Efek Indonesia terhadap kepemilikan manajerial. Berdasarkan analisis data dapat ditarik kesimpulan bahwa kinerja keuangan perusahaan retail yang terdaftar di Bursa Efek Indonesia terhadap kepemilikan manajerial, adalah: current assets dan debt to total assets berpengaruh positif dan signifikan sedangkan return on assets berpengaruh negatif dan signifikan terhadap kepemilikan manajerial retail yang terdaftar di Bursa Efek.Indonesia pada tahun 20142016.
\end{abstract}

\section{PENDAHULUAN}

Bisnis Ritel merupakan kegiatan bisnis baik barang maupun jasa yang mempunyai hubungan langsung dengan end user, baik konsumen tersebut bersifat pribadi maupun bukan pengguna bisnis, sehingga dalam kegiatannya selalu mendekatkan diri pada pasar konsumen akhir. Retail tidak hanya berarti menjual barang atau jasa saja secara instore (di toko atau outlet) namun dapat juga berupa nonstore (di luar toko atau outlet) dapat juga melalui katalg yang disebarkan kepada pelanggannya atau dari sebuah situs atau aplikasi berbasis online, dapat juga dilakukan penjualan secara langsung.

Banyak perusahaan-perusahaan retail yang telah go public, perusahaan yang telah melempar sahamnya di pasar memiliki mekanisme sendiri dalam penentuan harga pasarnya yang secara umum dipengaruhi oleh permintaan dan penawaran nilai saham di lantai bursa. Harga pasar adalah salah satu perwujudan nilai persahaan di mata pemegang saham, karena keputusan untuk memegang, menahan dan melepas saham adalah keputusan dari pemegang saham, keputusan tersebut merupakan cerminan dari tindakan manajemen (Michell, 2006).

Pada perusahaan go public sudah sewajarnya apabila perusahaan memiliki tujuan yang sama dengan pengelola perusahaan atau pihak manajemen yaitu bagaimana memaksimalkan nilai perusahaan mereka. Hal yang menjadi menarik adalah ketika antara pihak manajemen dan pemegang saham memiliki persepsi yang berbeda dalam hal strategi perusahaan, apalagi pemegang saham yang hanya memiliki saham dalam jumlah yang kecil. Sehingga rasa untuk memiliki perusahaan cenderung lemah. Selanjutnya manajer juga menginginkan keuntungan maksimal bagi dirinya selain harus selalu memaksimalkan dan menyenangkan bagi pemegang saham (Handono, 2008:6). 
Tujuan keuangan perusahaan dapat dilihat secara riil melalui analisis laporan keuangan. Analisis laporan keuangan dapat dilakukan menggunakan rasio keuangan. Rasio-rasio yang dugunakan untuk menilai kinerja keuangan perusahaan seperti rasio likuiditas, rasio leverage, rasio aktivitas, dan rasio profitabilitas. Analisis rasio memungkinkan manajer keuangan dan pihak yang berkepentingan untuk mengevaluasi kondisi keuangan akan menunjukkan sehat atau tidaknya suatu perusahaan (Afriyanti, 2011). Analisis rasio juga menghubungkan unsur-unsur rencana dan perhitungan laba rugi sehingga dapat menilai efektivitas dan efesiensi perusahaan.

Peningkatan value bagi perusahaan semakin mudah untuk diraih apabila ada kerjasama dari pihak manajemen sebagai pengendali perusahaan dan pihak lain dalam lingkup shareholder maupun stakeholder mempunyai keputusan keuangan untuk memaksimalkan modal kerjanya. Pada teori agensi keadaan dimana keputusan antara manajer perusahaan dengan investor tidak berjalan sesuai yang diharapkan, hal ini menimbulkan masalah, permasalahan yang ditimbukan oleh perbedaan kepentingan antara manajer perusahaan dengan para investor atau pemegang saham adalah merupakan masalah agensi (agency problem). Keadaan pada agency problem menyebabkan tidak tercapainya tujuan keuangan perusahaan (Diyah dan Erman, 2009).

Hubungan keagenan manajer sebagai pihak yang memiliki akses langsung terhadap informasi perusahaan, memiliki asimetris informasi terhadap pihak eksternal perusahaan, seperti kreditor dan investor. Dimana ada informasi yang tidak diungkapkan oleh pihak manajemen kepada pihak eksternal perusahaan, termasuk investor. Untuk memperkecil asimetris informasi, maka pengelolaan perusahaan harus diawasi dan dikendalikan untuk memastikan bahwa pengelolaan dilakukan dengan penuh kepatuhan kepada berbagai peraturan dan ketentuan yang berlaku. Upaya ini menimbulkan apa yang disebut sebagai agency costs, yang menurut teori ini harus dikeluarkan sedemikian rupa sehingga biaya untuk mengurangi kerugian yang timbul karena ketidakpatuhan setara dengan peningkatan biaya enforcement-nya

Penelitian ini bertujuan untuk mendapatkan bukti secara empiris tentang pengaruh kinerja keuangan perusahaan retail yang terdaftar di Bursa Efek Indonesia terhadap kepemilikan manajerial. Adapun kegunaan dari penelitian ini diharapkan dapat memberikan tambahan informasi mengenai pengukuran kinerja keuangan dan kepemilikan manajerial retail yang terdaftar di Bursa Efek Indonesia.

\section{Kerangka Konsep dan Hipotesis}

Kepemilikan manajerial merupakan pemegang saham dari pihak manajemen yang secara aktif ikut dalam pengambilan keputusan perusahaan (Wahidawati, 2002:5). Kepemilikan manajerial akan mensejajarkan kapantingan manajemen dan pemegang saham, sehingga akan memperoleh manfaat langsung dari keputusan yang diambil serta menanggung kerugian sebagai konsekuensi dari pengambilan keputusan yang salah (Marcus, Kane dan Bodie, 2006:8).

Downes dan Goodman (Etty Murwaningsari, 2009) kepemilikan manajerial adalah para pemegang saham yang juga berarti dalam hal ini sebagai 
pemilik dalam perusahaan dari pihak manajemen yang secara aktif ikut dalam pengambilan keputusan pada suatu perusahaan yang bersangkutan. Dalam teori keagenan dijelaskan bahwa kepentingan manajemen dan kepentingan pemegang saham mungkin bertentangan. Hal tersebut disebabkan manajer mengutamakan kepentingan pribadi, sebaliknya pemegang saham tidak menyukai kepentingan pribadi manajer tersebut, karena pengeluaran tersebut akan menambah biaya perusahaan yang menyebabkan penurunan keuntungan perusahaan dan penurunan deviden yang akan diterima. Etty Murwaningsari (2009).

Demsetz dan Lehn (1985) menyajikan beberapa argumen untuk hipotesa bahwa insider ownership dapat bervariasi diantara perusahaan-perusahaan. Umumnya, manfaat-manfaat dari insider ownership dihubungkan dengan tambahan dalam potensi kontrol dari para manajer yang mengambil andil besar dalam perusahaan. Biaya dari insider ownership ditanggung oleh para insider yang harus mengalokasikan sebagian besar dari kekayaan mereka untuk perusahaan, dan harus memegang suatu portofolio yang tak terdifersivikasi (undiversified). Di sisi lain, manajer juga mempunyai kecenderungan untuk menggunakan hutang yang tinggi bukan atas dasar maksimalisasi nilai perusahaan, melainkan untuk kepentingan oportunistik mereka. Hal ini akan meningkatkan beban bunga pinjaman karena risiko kebangkrutan perusahaan meningkat, sehingga agency cost of debt semakin tinggi.

Rasio likuiditas merupakan rasio yang menggambarkan kemampuan perusahaan untuk menyelesaikan kewajiban jangka pendeknya. Rasio likuiditas dalam penelitian ini diproksikan dengan current ratio. Current ratio merupakan rasio yang menunjukkan kemampuan perusahaan dalam memenuhi kewajiban finansial jangka pendeknya dengan menggunakan aktiva lancarnya (Hapsari, 2012).

\section{$H_{1}$ : terdapat pengaruh pengaruh current ratio terhadap kepemilikan manajerial pada perusahaan retail di Bursa Efek Indonesia}

Rasio pengembalian aktiva (return on assets) merupakan salah satu bentuk dari rasio profitabilitas yang dimaksudkan untuk mengukur kemampuan perusahaan atas keseluruhan dana yang ditanamkan dalam aktivitas yang digunakan untuk aktivitas operasi perusahaan dengan tujuan menghasilkan laba dengan memanfaatkan aktiva yang dimilikinya (Brigham dan Houston, 2006:109). Rasio ini merupakan ukuran yang berfaedah jika seseorang ingin mengevaluasi seberapa baik perusahaan telah memakai dananya. Oleh karena itu, return on asset kerap kali digunakan oleh manajemen puncak untuk mengevaluasi unit-unit bisnis di dalam suatu perusahaan multinasional Henry (2000:530)

Rasio profitabilitas menggambarkan kemampuan perusahaan mendapatkan laba melalui semua kemampuan dan sumber yang ada. Menurut Kamaludin dan Rini (2012:57), rasio profitabilitas merupakan rasio untuk mengukur profitabilitas kumulatif. Rasio profitabilitas dalam penelitian ini diproksikan dengan return on total assets (ROA) untuk mengukur profitabilitas 
perusahaan. Profitabilitas merupakan kemampuan perusahaan dengan keseluruhan modal yang ditanam dalam aktiva yang digunakan untuk menghasilkan keuntungan. Bentuk dari profitabilitas adalah Return on Asset (ROA) yang dapat diketahui dengan membandingkan antara keuntungan yang diperoleh setelah pajak (earning after tax) dengan jumlah investasi atau aktiva yang digunakan untuk menghasilkan keuntungan tersebut (Munawir, 1995)

\section{$H_{2}$ : terdapat pengaruh return on assets terhadap kepemilikan manajerial pada perusahaan retail di Bursa Efek Indonesia}

Rasio leverage menunjukkan seberapa besar aset perusahaan dibiayai oleh hutang atau seberapa besar hutang perusahaan berpengaruh terhadap pengelolaan aktiva (Aryani dan Widhiari, 2015). Rasio leverage dalam penelitian ini diproksikan dengan total debt to asset ratio (DAR). DAR merupakan rasio yang digunakan untuk mengukur bagian aktiva yang digunakan untuk menjamin keseluruhan kewajiban atau hutang yang dimiliki perusahaan.

\section{$H_{3}:$ terdapat pengaruh debt to total assets terhadap kepemilikan manajerial pada perusahaan retail di Bursa Efek Indonesia}

\section{METODE PENELITIAN}

Jenis penelitian yang digunakan adalah jenis penelitian explanatory research. Kerlenger (2001:98) Sampel dalam penelitian ini adalah perusahaan retail yang terdaftar di Bursa Efek Indonesia pada tahun 2014-2016. Penelitian ini termasuk penelitian kuantitatif. Variabel yang digunakan adalah variabel bebas antara lain yaitu: (1) current ratio, (2) ROA dan (3) DAR sedangkan variabel terikatnya adalah agency cost sebagai indikator dari kepemilikan manajer. Jenis data yang digunakan yaitu data sekunder berupa laporan keuangan perusahaan

Retail periode 2014-2016 yang di download Bursa Efek Indonesia (www.idx.co.id). Populasi penelitian yakni seluruh perusahaan retail yang terdaftar pada Bursa Efek Indonesia periode tahun 2014-2016. Metode pengumpulan data yang digunakan yakni purposive sampling, Berdasarkan metode purposive sampling, maka didapatkan 21 sampel perusahaan yang memenuhi kriteria yaitu tidak membukukan laba negatif selama tahun pengamat, setelah diteliti terdapat 12 perusahaan yang masuk pada kriteria sampel.

Variabel independen (bebas) sering disebut variabel stimulus, prediktor ticedent (Sugiyono, 2012:59) pada penelitian ini adalah :

\section{Current Ratio $\left(\mathrm{X}_{1}\right)$}

Likuiditas diukur dengan current ratio dapat dirumuskan (Hapsari, 2012)

$$
\mathrm{CR}=\frac{\mathrm{CA}}{\mathrm{CL}}
$$

\section{Return on Asset $\left(\mathrm{X}_{2}\right)$}


Berdasarkan (Hapsari 2012) dan Yustika (2015) profitabilitas diukur dengan return on total assets (ROA)

$$
\text { ROA }=\frac{\text { Laba Bersih }}{\text { Total asset }}
$$

3.Debt to Ratio $\left(\mathrm{X}_{3}\right)$

Leverage (Yustika, 2015) rasio idiukur dengan total debt ratio (DAR) dapat dihitung dengan rumus:

$$
\text { DAR }=\frac{\text { Total hutang }}{\text { Total asset }}
$$

Variabel dependen (terikat) sering disebut sebagai variabel output, kriteria, konsekuen (Sugiyono, 2012:59) pada penelitian ini adalah : kepemilikan manajerial (Y) variabel ini yaitu kepemilikan manajerial. Dalam (Yustika, 2015) kepemilikan manajerial diukur dengan agency cost dapat dihitung dengan rumus:

$$
\text { Agency Cost }=\frac{\text { biaya administrasi umum }}{\text { penjualan atau pendapatan }}
$$

Pengumpulan data menggunakan metode dokumentasi yakni mengumpulkan data laporan keuangan pada perusahaan retail (eceran) yang diunggah pada situs resmi Bursa Efek Indonesia periode tahun 2014-2016. Teknik analisis data menggunakan analisis regresi linear berganda dengan program SPSS versi 21.oo. Analisis regresi linear berganda dilakukan untuk mengetahui ada tidaknya pengaruh signifikan antara variabel bebas dengan variabel terikat. Model regresi yang digunakan untuk menguji hipotesis adalah sebagai berikut:

$$
\begin{array}{ll}
\text { Rumus: } \mathrm{Y} & =\mathrm{a}+\mathrm{b}_{1} \mathrm{X}_{1}+\mathrm{b}_{2} \mathrm{X}_{2}+\mathrm{b}_{3} \mathrm{X}_{3}+\mathrm{e} \\
\text { dimana: } & \\
\text { a. } & =\text { kepemilikan manajerial } \\
\mathrm{A} & =\text { konstanta } \\
\mathrm{b} 1, \mathrm{~b} 2 & \\
\mathrm{~b} 3 & =\text { koefisien regresi } \\
\mathrm{X}_{1} & =\text { current ratio } \\
\mathrm{X}_{2} & =\text { return on assets } \\
\mathrm{X}_{3} & =\text { total debt ratio } \\
\mathrm{e} & =\text { error }
\end{array}
$$

Pengujian regresi linear berganda yang baik adalah terbebas dari gejala normalitas, multikolonieritas, autokolerasi dan heteroskedastisitas, sehingga sebelum melakukan model regresi terlebih dahulu akan dilakukan pengujian asumsi klasik. Uji asumsi klasik menggunakan uji normalitas, ujimultikolonieritas, uji autokolerasi, dan uji heteroskedastisitas.

\section{HASIL DAN PEMBAHASAN}

a. Hasil penelitian besarnya $t_{\text {hitung }}$ sebesar 3,562 dan $t_{\text {tabel }} 2,021$ menunjukkan bahwa terdapat pengaruh positif dan signifikan current 
ratio terhadap kepemilikan manajerial pada perusahaan retail di Bursa Efek Indonesia.

b. Hasil penelitian besarnya $t_{\text {hitung }}$ sebesar $-2,192$ dan $t_{\text {tabel }}-2,021$ menunjukkan bahwa terdapat pengaruh negatif dan signifikan return on assets terhadap kepemilikan manajerial pada perusahaan retail di Bursa Efek Indonesia.

c. Hasil penelitian besarnya $t_{\text {hitung }}$ sebesar 3,291 dan $t_{\text {tabel }} 2,021$ menunjukkan bahwa terdapat pengaruh positif dan signifikan debt to total assets terhadap kepemilikan manajerial pada perusahaan retail di Bursa Efek Indonesia.

d. Hasil penelitian besarnya $F_{\text {hitung }}$ sebesar 6,219 dan $F_{\text {tabel }} 2,80$ derajat signifikansi adalah 0,002 menunjukkan bahwa terdapat pengaruh positif dan signifikan current ratio, raturn on assets dan debt tot total assets secara simultan terhadap kepemilikan manajerial pada perusahaan retail di Bursa Efek Indonesia.

Analisis data menunjukkan pengaruh positif dan signifikan current ratio terhadap kepemilikan manajerial pada perusahaan retail di Bursa Efek Indonesia. Hasil ini menunjukkan bahwa semakin tinggi kemampuan perusahaan memenuhi kewajiban jangka pendeknya maka semakin besar agensi cost (kepemilikan manajerial). Begitupula sebaliknya semakin rendah kemampuan perusahaan memenuhi kewajiban jangka pendeknya maka semakin kecil agensi cost (kepemilikan manajerial), profitabilitas berpengaruh terhadap agensi cost (kepemilikan manajerial) pada perusahaan retail yang terdaftar di Bursa Efek Indonesia (BEI) tahun 2014-2016.

Hasil analisis data terdapat pengaruh negatif dan signifikan return on assets terhadap kepemilikan manajerial pada perusahaan retail di Bursa Efek Indonesia. Hasil ini menunjukkan arah yang sebaliknya (Munawir, 1995), yang menekankan bahwa salah satu kegiatan prinsipal yang bersifat menyeluruh, apabila perusahaan sudah menjalankan praktik akuntansi yang baik maka manajemen dengan menggunakan teknik analisis ROA dapat mengukur penggunaan modal yang tertanam dari asset perusahaan. Apabila profit margin telah mencapai target atau standar yang telah ditetapkan, sedangkan operating assets masih dibawah target maka perhatian manajemen dapat dicurahkan untuk memperbaiki kebutuhan investasi baru dalam modal kerja maupun dalam aktiva tetap. Pada perusahaan retail retrun on assets yang menurun justru meningkatkan biaya agensi.

Hasil perhitungan menunjukkan pengaruh positif dan signifikan debt to total assets terhadap kepemilikan manajerial pada perusahaan retail di Bursa Efek Indonesia. Pembuktian tersebut mengacu pada biaya keagenan perusahaan dengan struktur modal seperti itu lebih tinggi (Jensen dan Meckling, 1976:354). Tambahan informasi diperlukan untuk menghilangkan keraguan pemegang obligasi terhadap dipenuhinya hak-hak mereka sebagai kreditur (Schipper dalam Marwata, 2001) dan Meek, et al dalam Fitriani (2001). Oleh karena itu perusahaan dengan rasio leverage yang tinggi memiliki kewajiban untuk 
melakukan ungkapan yang lebih luas daripada perusahaan dengan rasio leverage yang rendah.

Penelitian ini mendukung teori sebelumnya bahwa semakin tinggi debt to total assets menunjukkan semakin menguat kepemilikan manajerial.

\section{PENUTUP}

\section{Kesimpulan}

Berdasarkan analisis data dapat ditarik kesimpulan bahwa kinerja keuangan perusahaan retail yang terdaftar di Bursa Efek Indonesia terhadap kepemilikan manajerial. Current assets dan debt to total assets berpengaruh positif dan signifikan sedangkan return on assets berpengaruh negatif dan signifikan terhadap kepemilikan manajerial retail yang terdaftar di Bursa Efek.Indonesia pada tahun 2014-2016.

\section{Saran}

Bagi investor apabila akan berinvestasi pada suatu perusahaan agar memperhatikan aspek return on assets, kepemilikan manajerial dan debt to total assets karena faktor-faktor tersebut mempengaruhi kepemilikan manajerial.

\section{DAFTAR PUSTAKA.}

Aryani, Ayu dan Widhiari, Lely. 2015. Pengaruh Rasio Likuiditas, Laverage, Operating Capacity, Dan Sales Growth Terhadap Financial Distress. Jurnal Akuntansi. Universitas Udayana Vol.11 No, 2 Hal: 456-469.

Brigham, Eugene F. dan Houston Joel F.. 2006. Dasar-Dasar Manajemen Keuangan. Diterjemahkan Oleh: Ali Akbar Yulianto. Edisi Kesepuluh. Jakarta: Salemba Empat.

Diyah Pujiati dan Erman Widanar. 2009. Pengaruh Struktur Kepemilikan Terhadap Nilai Perusahaan: Keputusan Keuangan Sebagai Variabel Intervening. Jurnal Ekonomi Bisnis \& Akuntansi Ventura.

Ghozali, Imam. 2011. Aplikasi Analisis Multivariat Dengan Program SPSS. Semarang:Badan Penerbit Universitas Diponegoro

Handono Mardiyanto. 2008. Inti Sari Manajemen Keuangan. Jakarta: Grafika.

Hapsari, Indri. 2012. Kekuatan Rasio Keuangan Dalam Memprediksi Kondisi Financial Distress Perusahaan Manufaktur Di BEI. Jurnal Manajemen. Universitas Negeri Semarang Vol.3 No, 2 Hal: 101-109.

Henry Simamora. 2000. Akuntansi Basis Pengambilan Keputusan Bisnis. Jakarta: Salemba Empat.

Kamaludin dan Indriani, Rini. 2012. Manajemen Keuangan “ Konsep Dasar dan Penerapannya, Edisi Revisi. Bandung:CV Mandar Maju

Marcus, Kane dan Bodie. 2006. Investment. Jakarta: Salemba Empat.

Michell Suharli. 2006. Studi Empiris Terhadap Faktor Yang Mempengaruhi Nilai Perusahaan Pada Perusahaan Go Public di Indonesia. Jurnal Manajemen, Akuntansi dan Sistem Informasi.

Sugiyono. 2009. Metodologi Penelitian Bisnis. Bandung: Alfabeta. 
Sugiyono. 2012. MetodePenelitian Kuantitatif Kualitatif dan $R \& D$. Bandung: Alfabeta.

Wahidawati. 2002. Kepemilikan Maajerial dan Kepemilikan Institusional pada Kebijakan Hutang Perusahaan: Sebuah Prospektif Theory Agency. Jurnal Riset Akuntansi Indonesia.

Yustika, Yeni. 2015. Pengaruh Likuiditas, Leverage, Profitabilitas, Operating Capacity Dan Biaya Agensi Manajerial Terhadap Financial Distress (Studi Empiris pada Perusahaan Manufaktur yang Terdaftar di Bursa Efek Indonesia Tahun 2011-2013). Jurnal Fakultas Ekonomi. Universitas Pekanbaru Vol. 2 No, 2 Hal: 1-15. 